This is a peer-reviewed, accepted author manuscript of the following research article: Ravenscroft, J., Davis, J., Bilgin, M., \& Wazni, K. (2019). Factors that influence elementary school teachers' attitudes towards inclusion of visually impaired children in Turkey. Disability and Society, 34(4), 629-656.

https://doi.org/10.1080/09687599.2018.1561355

\title{
Factors that Influence Elementary School Teachers' Attitudes towards Inclusion of Visually Impaired Children in Turkey
}




\section{Abstract}

There is a scarcity of research on inclusion of visually impaired children in Turkey. Specifically, a gap exists concerning the attitudes of elementary school teachers towards the inclusion of visually impaired children in mainstream schools. This paper uses data from two questionnaires, leveraging the responses of 253 teachers from rural and urban areas. The results demonstrate that elementary school teachers commonly hold positive attitudes towards the inclusion of visually impaired children and that teachers' initial and in-service training about inclusion positively influenced their attitudes. Our findings are in contrast with earlier research which argues teachers do not hold positive attitudes to inclusion, and highlights that a key barrier to inclusion stems from elementary school teachers feeling unprepared to teach visually impaired children. We conclude that greater post-qualification training is required to enable teachers to operationalize different approaches that facilitate the inclusion of visually impaired children.

Keywords: Childhood Visual Impairment, Inclusive Education, Teacher Training, Turkish Elementary Schools, Disability, Inclusion 


\section{Points of Interest}

- A majority of teachers in Turkish Elementary Schools hold positive views towards inclusion of visually impaired children.

- Teachers' pro-inclusion attitudes regarding visually impaired children are more prevalent in rural settings and relate to closer community-based relationships.

- Teachers' pro-inclusion attitudes regarding visually impaired children are also related to peer support and their colleagues' knowledge and experience of inclusion.

- Experiencing inclusive practices during initial training and further professional development leads to a more positive attitude towards inclusion.

- Gender, age, and years of experience do not significantly influence teachers' attitudes towards the inclusion of visually impaired children in Turkey. 


\section{Introduction}

The paper builds on a variety of literature, including articles in Disability and Society to answer the following questions: (i) have professional attitudes towards inclusion changed in elementary schools in Turkey?; (ii) what factors have influenced that change?; and, (iii) what factors (e.g. rurality, colleagues' support and experience of childhood diversity) impact teachers' willingness to develop inclusion with visually impaired children?

The voices of disabled children and their ability to take leadership roles in schools are key aspects that change educational settings and create greater awareness of diverse identities (Davis and Watson 2002; Garth and Aroni, 2003). Disabled children can provide expert knowledge on restructuring learning environments, enabling equity, and promoting fairness (Davis, Ravenscroft, and Bizas 2014; Davis and Deponio, 2014). This paper does not include the voices of disabled children as it is specifically concerned with a survey of professional perspectives on inclusion. However, we have reported on children's voices/perspectives of inclusion in many other publications including Davis, Ravenscroft, and Bizas, (2014) and Ravenscroft, Wazny, and Davis (2017), and references therein.

This study was motivated by literature that argued in order to see a change in adult attitudes, removal of barriers to learning for disabled children is imperative (Allan, 2010; Davis and Deponio, 2014). Such research has connected positive experiences of inclusion with processes that have enabled professionals to restructure, reassess, and re-evaluate their attitudes, cultures, and practices. Consequently, our study sought to identify the specific factors that teachers believed influenced a change in professional attitudes.

Up until the 1990s, the full participation of disabled children was not substantially encouraged within the Turkish school environment (Polat 2011). In 1997, the Special Education Statutory Decree (No: 573) was published with the aim of reducing regulatory barriers against the implementation of inclusion. It stated, "Children with special needs shall 
be educated in the least restrictive environments with their non-disabled peers." This decree increased the number of children included in general settings. However, despite this policy shift in Turkey, disabled children who were educated in mainstream schools tended to only to be integrated into separate 'resource classrooms' for children with 'special needs' rather than experience full social and educational inclusion (Davis and Deponio 2014). Turkish research has connected such practices to a lack of knowledge on inclusion and a dearth of trained practitioners (Ciyer, 2010; Durak and Erkilic, 2012). As such, in practice, we see children being forced to fit into the pre-existing circumstances, in-line with Ainscow's definition of ‘integration’ (Ainscow, 2000).

Research in Turkey between 1999 and 2010 demonstrated that the majority of teachers held negative attitudes towards inclusion (Diken and Sucuoğlu 1999; Metin and Çakmak 1998; Rakap and Kaczmarek 2010; Uysal, 2004). Further research comparing approaches to inclusion in Bulgaria and Turkey with other European countries argued that a focus on 'special needs identification' meant that professionals with a tradition of working within a medical model continued to invest substantial time testing and separating children, rather than focusing on working with children to establish their views, find solutions, and to identify the best way from the child's perspective to foster inclusion (Panayotova 2009).

The aspiration to move from integration to inclusion in Turkey has been enshrined in more recent policies that require all schools to restructure educational provisions to promote the child's belonging and ensure each child has equal opportunities for full participation (Kunc 1992; Avramidis, Bayliss, and Burden 2000). For example, the Turkey $9^{\text {th }}$ Annual Development Plan 2007-13 aimed to place greater focus on inclusion and equity in schools, teacher skills, evaluation, and quality management; in addition, the Turkish government has enacted a series of other policy changes to promote inclusion (Erkilic and Durak 2013). 
Currently, educational policy in Turkey specifically sets out the key tenants of inclusive education concerning how to put policy into practice. Yet, recent European projects that have studied inclusion have argued the existence of a lack of in-depth training on inclusion and a dearth of practical examples of how to foster inclusive practice, specifically in countries such as Bulgaria and Turkey. In particular, this research demonstrates that despite professionals having an understanding of the social model and understand disabled children's right to inclusive education, they do not possess the knowledge on facilitating inclusion in practice.

It has been argued that inadequate teacher training programs and a gap between theory and practice continue to form some of the primary obstacles to implementing successful inclusive education in schools in Turkey (Sak1z and Woods 2015). Davis and Deponio (2014) argued that in Turkey, teachers only possessed very general knowledge concerning disability and inclusion. Moreover, the authors found there was a lack of contemporary knowledge and information within initial teacher education courses concerning how to remove barriers to learning for children who experienced specific impairments, such as dyslexia (Davis \& Deponio 2014).

Whilst this research illuminates the situation in Turkey, it should not be assumed that it is not heterogeneous. European cross-cultural research has been criticised for assuming homogeneity within a country or culture (Davis, Ravenscroft, and Bizas 2014; Borket and De Tona 2006). This study examines whether professionals in different settings in Turkey (e.g. rural and urban) differ on their views of inclusion.

In recent years, partial reforms have taken place in Turkey in an attempt to tackle barriers to inclusion (e.g. Circular for Educational Practices via Inclusion MoNE 2008 and Special Education Services Bylaws 2012). However, research suggests that little attention has been placed on how to support teachers to put theory into practice and to enable teachers to 
access support services related to inclusion in Turkish public schools (Batu, Kircaali-Iftar, and Uzuner 2004; Özaydın and Çolak 2011). For example, Melekoglu (2014) found that when teachers approached guidance counsellors for support on inclusive education, the guidance counsellors themselves did not have sufficient knowledge to be a resource for inclusive practice. Similarly, Akalın, et al. (2014) demonstrated teachers lacked in-depth practical knowledge of inclusion and argued that a lack of support negatively influenced the attitudes of teachers towards inclusion. This raised the question for our study: are teachers' attitudes to inclusion affected by their colleagues' knowledge and experience of inclusion and their colleagues' ability to provide peer support?

In spite of international policy aims on inclusion, it has been argued that in countries such as Bulgaria, Turkey, and New Zealand 'a higgledy-piggledy approach' to inclusion has emerged. 'A higgledy-piggledy approach' to inclusion is defined as occurring when governments claim to support inclusion, but mainstream professionals are confused about what actually constitutes inclusive practice. Professional confusion stems from: (i) a lack of focus on mainstream classroom solutions; (ii) a scarcity of sharing/enabling of sustained inclusive practice; (iii) a failure to challenge traditional practices of exclusion; and, (iv) a preponderance of itinerant specialist teachers/classes (Higgins, MacArthur, and Rietveld 2006).

Ainscow, Farrell, and Tweddle (2000) have argued that inclusion can be defined in a variety of ways and does not hold the same meaning for each child. Their position, that inclusion includes diversity, is in line with writing in disability studies and Disability and Society which analyses the strengths and weaknesses of complex post-structural perspectives of disability (e.g. Corker and Shakespeare 2002; Meekiisha and Shuttleworth, 2009; McGrath, Rudman, Trentham et al. 2017).

Writers in Disability and Society, such as Symeonidou (2017), have been critical of simplistic arguments concerning teachers' attitudes to inclusion, have questioned the role and 
approaches of professionals who enable teacher training and questioned how training impacts on change. Indeed, our paper builds on the work of Symeonidou (2017) by concluding that simplistic approaches to teacher education that have been espoused within the discipline of 'special education' (e.g. Florian 2008) tend to overemphasize the need for teachers to make decisions, promote a definition of inclusive education that irons out bodily difference, misrepresents the key founding principle of inclusive education as disregarding notions of difference and fails to engage with writing in journals such as Disability and Society that have traditionally critiqued generic ideas of inclusion.

Connors and Stalker, for example, writing in Disability and Society in 2006 (but ignored by Florian 2008) were extremely critical of interventions into disabled children's lives that aimed to remove differences rather than work with the positive aspects of diversity and identity. They highlighted the need for us to recognise children's, parents', and teachers' abilities to manage concepts of difference and promote positive and complex identities in educational settings.

Since 2006, such arguments have been enshrined in the affirmative model of disability (Cameron 2008). This model clarified the relationship between disability and impairment in a similar way to the work of others in disability studies who sought to connect the social model to notions of embodiment (e.g. Corker and Shakespeare 2002; Corker and Davis 2000; Paterson and Hughes 1999). The affirmative model of disability extended the traditional materialist social model to include the idea that disability prejudice is related to the way that society expects and requires a person with a specific impairment to be. This model provided a framework for understanding and acknowledging disabled people's complex identities at the same time as enabling us to grasp that a person's impairment forms an essential part of his or her identity and difference due to disability is not always negative (Cameron 2011). The affirmative model rejects ideas of charity and tragedy that constrain 
what disabled people can do and by reframing impairment as an everyday aspect of our lives that forms our self-identity and should not prevent disabled people from being fully accepted into communities (Cameron 2011; Swain and French 2000). Such writing raises questions concerning what types of communities are better placed to enable inclusive education and towards the end of the paper; we connect those questions to the idea that children themselves define social justice and inclusion as the opportunity to experience strong community-based relationships. Such an analysis provides an innovative focus that stretches our understanding of the conditions that teacher training should consider if teachers are to engage fully with disabled children's right to inclusive education and builds on writing in Disability and Society that has argued rather than neo-liberal approaches to education, what is required is an approach that recognises and builds from the unique needs, aspirations, and ambitions of disabled children and young people within our and their communities (Burch 2018).

In terms of the negative aspects of impairment, explained in the affirmative model, it has been argued that the type of impairment experienced by a pupil influences a teachers' attitude towards that pupil's inclusion. For example, some teachers who are less experienced in teaching pupils with visual impairment are less positive about inclusion (Ryan 2009). Such research suggests that teachers, schools, and parents are more likely to have a positive attitude towards the inclusion of visually impaired pupils when they had more experience working and communicating with visually impaired pupils in settings that are flexible to different pupils' requirements (e.g. take greater steps to adapt the physical environment to be more inclusive) (Ryan 2009; Lane 2008; Wall 2002).

Visually impaired children require materials and teaching methods that may differ from those used by general education mainstream teachers in general settings, such as the use of Braille and access to technology to ensure that visually impaired children can access the curriculum (Lohmeier, Blankenship, and Hatlen, 2009; Lewis, Savaiano, Blankenship, and 
Greeley-Bennett 2014). Specialist visual impairment teachers refer to this reasonable adjustment as the Expanded Core Curriculum (ECC). Due to the additional support needs, and previous research in inclusion with visually impaired children, we sought to investigate whether recent changes to teacher training and policy on the inclusion of visually impaired children had impacted on teachers' attitudes in Turkey. We also sought to study whether teachers' experiences of working with children with specific impairments influenced their attitude to inclusion.

The inclusion policy in Turkish schools states that disabled children must have individualized education plans and must be educated in relation to the general school curriculum (MoNE 2010). Teachers of visually impaired children and elementary school teachers can use the Curriculum for the Blind to address the needs of visually impaired children (MoNE 1990). However, it should be noted that the Curriculum for the Blind (and accompanying teacher guide) has been critiqued for lacking clarity and for not being updated since 1990 (Arslantekin 2015).

The appointment of teachers of children with visual impairment is controlled by The Ministry of National Education in Turkey (Çakıroğlu and Çakıroğlu 2003) and their statistics (MoNe 2017) indicate that 1,283 visually impaired children were educated in seventeen special elementary schools, seventeen special middle schools, and two special high schools for the blind in the 2016-2017 school year. Under decree 573 of the Ministry of National Education, teachers of visually impaired children can find positions in special schools for the blind or they can be employed as itinerant/peripatetic teachers in mainstream settings. Despite the statutory decree, a 2011 report argued that itinerant teachers had not been sufficiently recruited in mainstream settings and general education teachers were not receiving support from specialist teachers with regard to how to adapt the curriculum to the requirements of visually impaired children (Education Reform Initiative 2011). 
Since 1987 The Gazi University has been the only institute for training teachers of visually impaired children in a 4-year undergraduate program since 1987 (Melekoglu, Cakiroglu, and Malmgren 2009). Internationally, the mainstream teaching of visually impaired has been critiqued on the basis that:

- There is a lack of reasonable adjustment; e.g. traditional education strategies deliver information through visual materials as primary sources and require developed visual skills.

- General education classroom design creates learning barriers for visually impaired children.

- Teachers lack specialized materials to meet visually impaired children's individual needs; e.g. alternative forms of presenting visual information, utilizing tactual, and auditory educational tools. (American Foundation for the Blind 2011; Pogrund and Wibbenmeyer 2008).

Such gaps can be connected to research that argues that a lack of quality in teacher preparation, teaching skills, and a shortage of qualified specialists present challenges in schools and impact on teachers' attitudes towards the inclusion of children (Saunders 2012). Other studies, such as those reported in Disability and Society, indicate that personal attitudes, limited resources, a lack of training, and a lack of peer support impact school teachers' abilities to successfully implement inclusive education (McCarthy and Shevlin 2017; Cook, Swain and French 2010). Therefore, our article seeks to contribute to discussions in this journal and our field, internationally, concerning which factors instigate a change in teacher attitudes and what support is required to achieve such a change. 


\section{Summary of Research Questions:}

This paper seeks to answer several key questions:

1. What different factors influence teachers' perspectives on, and ability to, foster the inclusion of visually impaired children?

2. Do teachers' perspectives on inclusion relate to factors such as: (i) their knowledge and experience of inclusion; (ii) their individual and demographic characteristics (e.g., age, gender, etc.); (iii) their colleagues' knowledge and experiences; and, (iv) the different settings in which they teach (e.g. rural and urban)?

3. What drivers (if any) motivate teachers in Turkey to change their attitudes?

\section{Research Process:}

In order to answer the questions posed above, we surveyed a sample of elementary school teachers from urban and rural schools in Turkey and conducted an exploratory analysis of the factors that influenced teachers' attitudes concerning the inclusion of visually impaired children in Turkish mainstream elementary schools.

\section{Participants}

Konya is the biggest city in Turkey by geographic area and is located in the Central Anatolia Region. Out of thirty-one districts, thirteen were selected at a distance of an average of seventy-five miles to the city centre of Konya for transport accessibility reasons. The names and addresses of the public schools were requested from the Ministry of National Education. We used stratified random sampling to ensure responses from both rural and urban participants. 351 questionnaires were distributed; 253 elementary school teachers in 13 districts in Konya responded with completed questionnaires (72.1 percent response rate). We defined respondents as working in an urban district if the population was over 50,000 and 
rural if the population was less than 50,000 (Ratcliffe, Burd, Holder, and Fields 2016). Among the teachers surveyed, 161 (64 percent) were working in urban districts, 89 (35 percent) were from rural areas, and 3 (1 percent) participants did not disclose their districts. 95 (38 percent) elementary schools teachers had at least one included student with disabilities in their classrooms. Over a third of participants (34 percent) had less than six years of experience. Participants' details are presented in Table 1. This is the largest study conducted to-date regarding teachers' attitudes towards inclusion of visually impaired children in the Republic of Turkey.

Insert Table 1 about here

\section{Ethics}

Ethical approval was obtained from the Moray House School of Education, University of Edinburgh, and from the Ministry of National Education in Turkey. The ethical principles of research, outlined by the British Psychological Society, were followed throughout the study. Participants were informed about the nature of the study, benefits, and potential risks, as well as the right to withdraw on a covering letter. Verbal consent was obtained from the participants, and the anonymity of the participants was assured.

\section{Research Instruments}

The study questionnaire was conducted in two parts, see the Appendix. The first part surveyed the teachers' individual and demographic information, such as their experience, age, school, gender, training, and support. The second part included 15 statements exploring the teachers' attitudes towards visually impaired children. Research questions were phrased as a 
five-point Likert-type scale questionnaire. The research instruments were adapted from the Facilitating Inclusive Education and Supporting the Transition Agenda (FIESTA) project (Davis, Ravenscroft, and Bizas 2014) and the published study of Mushoriwa (2001). The Mushoriwa (2001) study was piloted with a group of 150 teachers before our use. The FIESTA questionnaire was piloted and validated through the FIESTA Project and was validated in all participating member countries. Validation of the FIESTA study was achieved by ensuring the questions were culturally sensitive and appropriate through initially carrying out three research team meetings with all FIESTA participant countries present to analyse the cross-cultural comparability of the research instrument. From this final set of questions, a Turkish translation was made and piloted. No questions were removed from the initial set of questions post-pilot.

\section{Procedure}

The survey was conducted by the third author physically delivering a hard copy to each school on the mornings of a regular school day and inviting each elementary school teacher who was present that day to take part in the study. The third author remained available to the teachers for an hour during the school day to answer any questions. The completed surveys were collected at the end of the school day, giving the participants almost a full school day to complete the survey.

After receiving the completed surveys, questions 8 to 18 from the first section of the questionnaire and 1 to 14 from the second section were transformed into a 1-5 scale with 1 being very negative and 5 being very positive. Findings from questions $1-10$ of the second section of the questionnaire were combined with the question "What is your personal view on inclusion?" and averaged in order to create a 'positivity score,' which is an individual-level indication of the degree of positivity of each teacher's view of inclusion. Some questions 
were deliberately phrased negatively in order to circumvent response bias (Appendix: questions $2,3,5,6,9,11,12$ ), and so that we did not miscalculate the scores, we transformed the negatively phrased questions to match the positively phrased ones before creating an individual positivity score for each participant. This was done by changing the 1 (which represented a double negative and would therefore been the equivalent to a very positive score) to a 5 , a 5 to a 1 , scores of 2 to 4 and 4 to 2 and the 3 (neutral/neither) scores remained the same. We, therefore, ensured that by transforming the scores there were no double negatives included in the analysis.

The 'positivity score' became our outcome. We measured other questions against this outcome using either t-tests or an ANOVA, depending upon whether there were two or three or more variables within them. Variables analysed with an ANOVA that were found significant were further analysed by post-hoc testing using the Tukey method, which adjusts for multiple testing using family-wise comparisons.

\section{Limitations}

The current study has several limitations. The study included a sample of teachers from the Central Anatolia Region of Turkey. The results of the research may not be generalizable to other cities or regions in Turkey. An additional qualitative study may have brought in-depth insight into the teachers' experiences and viewpoints about inclusion and strengthen the current research. In addition, the study did not directly set out to investigate the influence of the mandatory post-2009 inclusive education course. It is impossible to know from the data what effect, if any, the course has had on the teachers' attitudes towards inclusion. As the participation for the study was voluntary, it could be possible that teachers with more experience would volunteer if they knew about the aims of the study. Therefore, the results may not accurately reflect the target population and selection bias could be one of the limitations of this study. 


\section{Results}

Two separate sections report on the results. In the first section, the teachers' attitudes towards the inclusion of visually impaired children is examined. For the purpose of the analysis, a table created from the responses of 15 statements (Table 2) will be discussed as initial results, and individual 'positivity scores' are reported subsequently.

For analysis in this section, we combined the two positive options (agree (4) and strongly agree (5)) to be representative of a positive response. The two negative options (disagree (2) and strongly disagree 1)) were combined to represent a negative response. In terms of positive responses, the results show (34.52 percent option 4 and 26.19 percent option 5) that over 60 percent (60.71) of the participant's personal view on inclusion held positive attitudes towards the inclusion of disabled children in general elementary settings. Over one quarter of the participants (26.19 percent) of the sample very strongly supported inclusion. A greater proportion of teachers, (67.46 percent), believed inclusion increases the

child's circle of friends. Likewise, more than 66 percent (9.6 percent and 56.4 percent) of the teachers stated that they did not think inclusion would make children less well-adjusted, with nearly half of the sample (48.59 percent) indicated a positive awareness of other children's happiness with regard to playing with a child with visual impairment.

In contrast to those who hold positive views on inclusion, 34.4 percent of teachers believed that the inclusion of visually impaired children would limit the child's own academic performance within the school and a large minority of participants (43.49 percent) believed that inclusion added to the learning problems of the children with visual impairment. Conversely, more than half of the sample (54.61 percent) responded that inclusion would help the child with visual impairment develop confidence in his or her academic ability. 
A significant proportion of the participants ( 71.7 percent $)$ agreed that when a child with visual impairment is included, sighted children become more understanding visually impaired children, and 56.9 percent did not think that inclusion of a child with visual impairment in general education classrooms increased the amount of social rejection by the child's peers. In keeping with research that argues teachers supportive of the concept of inclusive education connect it with the benefits of peer support (Joy and Murphy 2012), our respondents connected the benefits of inclusion with a wider circle of friends and suggested peer support helped to develop the child's confidence in their own academic ability. When the elementary school teachers were asked directly within the questionnaire whether they would be happy having visually impaired children in their classes, the neutral/neither response (3) was the most common singularly indicated response with 36.9 percent of all responses. The remaining results show $34.1 \%$ of teachers were happy or very happy to have visually impaired children in their classes compared to $29.0 \%$ not happy or extremely not happy in including visually impaired children in their classroom.

In terms of teachers' knowledge and negative assumptions about impairment, 24.4 percent of the respondents indicate that they did not understand the problems associated with children with visual impairment; 57.7 percent believed they were not well prepared to teach visually impaired children effectively. Roughly, half of the teachers (51.8 percent) indicated that elementary school teachers do not make appropriate educational provisions for including children with visual impairment.

Insert Table 2 about here

\section{Results of the Positivity Scores}


Rural teachers' positivity score was higher than that of urban teachers' ( $\mu$ (rural population mean $)=3.51$ vs. $\mu($ urban population mean $)=3.29$, respectively, $M D=0.22, t=$ $2.328, \mathrm{df}=175.24, \mathrm{p}=0.02)$. The analysis suggests that rural teachers held more positive attitudes than urban teachers to the inclusion of visually impaired children in elementary mainstream settings.

Results from the one-way analysis of variance (ANOVA) on the positivity scores of teachers are presented in Table 3. The knowledge and experience of co-workers were identified as having an effect on teachers' positivity scores (those who ranked themselves as experienced differed from those who ranked themselves as neutral (MD: 0.37; 95\% CI, 0.04 to $0.70 \mathrm{p}=0.02$ ). Knowledge of co-workers was also a significant predictor; teachers who ranked their own knowledge as 4 (experienced) on the Likert scale compared to those who ranked as 3 (neutral/neither) had significantly higher positivity scores (MD: 0.37, 95\% CI 0.04 to $0.70,=0.19)$.

Training and experience gained during initial qualification was also predictive of positive scores in teachers $(\mathrm{p}=0.01)$. Post-hoc analysis, indicated that those ranking themselves as 4 (experienced) vs. 1 (very inexperienced) (MD: 0.39, 95\% CI 0.01 to $0.77, \mathrm{p}$ $=0.04)$ and 4 vs. 2 (inexperienced) (MD: $0.37,95 \%$ CI 0.04 to $0.70, \mathrm{p}=0.02)$ differed significantly in their positivity towards inclusion. Comparisons of those who ranked 4 (experienced) vs. 1 (very inexperienced) (MD: $0.57,95 \%$ CI: 0.13 to $1.01, p=0.004$ ) and 4 vs. 2 (inexperienced) (MD: $0.44,95 \% \mathrm{CI}, 0.12$ to $0.75, \mathrm{p}=0.002$ ) also indicated that continuous professional development training was a significant predictor of positivity towards inclusion.

Whether the teacher rated his or herself as being self-reflective also impacted the positivity scale. Teachers who scored themselves as highly reflective (Likert score 5) compared to those who scored themselves as neutral/neither (Likert Score 3) had higher 
positivity scores (MD: $1.04,95 \%$ CI 0.14 to $1.94, \mathrm{p}=0.02$ ). There was borderline significance in comparing teachers who scored themselves as neutral/neither having limited reflection (Likert scale 2) (MD: $0.54,95 \%$ CI -2.60 to $0.10, p=0.08$ ) to those who scored themselves as relatively reflective (Likert scale 4) (MD: $0.91,95 \% \mathrm{CI}: 0.00$ to $1.81, \mathrm{p}=$ 0.05). Gender, age, and years of experience of a teacher were not found to be a significant predictor of positivity. The results suggest that school-based experiences of teachers with developing or supporting inclusive practices are not significantly associated with positivity scores; however, experiencing good inclusion practices during initial training and further professional development were significantly associated with positivity scores. Indicating that learning by trial and error in the isolated context of the classroom did not leave teachers with the positive views on inclusion.

Insert Table 3 about here

Insert Table 4 about here

\section{Discussion}

Our results and analysis suggest that a change has occurred since earlier studies that highlighted teachers' negative attitudes towards inclusion, (e.g. Diken and Sucuoğlu 1999) and that general elementary school teachers are in fact positive towards the inclusion of disabled children (60.7 percent of 253 participants). Since 2009, teacher-training courses on inclusive education in Turkey have shifted from being an optional aspect of undergraduate 
teacher education to a mandatory requirement. Our study found that both training and experience on inclusion gained during initial qualifications and continuous professional development were predictive of teachers' positive views towards inclusion. This connects our findings to research in disability studies that have found barriers to inclusion are created when teachers do not have adequate professional development opportunities and training has not been connected with a shift towards mainstream resources (Armstrong and Galloway 1994; Barton and Armstrong 2007).

Our study confirmed the work of Rakap and Kaczmarek (2010), and Avramidis, Bayliss, and Burden (2000) who found that teacher age and teaching experience do not influence teachers' attitudes towards inclusion. However, our findings did not replicate research that suggests that female teachers have more positive attitudes than male teachers (Hastings and Graham 1995; Forlin, Loreman, Sharma, and Earle 2009), and that younger teachers are more enthusiastic about in including disabled children (Ahmmed, Sharma, and Deppeler 2014). Our data suggest that the length of teaching experience is not consequential for inclusion; rather, teachers' willingness, reflectiveness, mentorship opportunities, and knowledge of how to remove barriers to learning for/with disabled children are most important in forming their views on inclusion of children with visual impairment.

Previous research has argued that a national and embedded approach is necessary to overcome the patchy nature of inclusion between schools and within different areas of a country (Kinsella and Senior 2008). Some research has critiqued teacher educators for being poorly equipped to promote inclusive education and called for greater efforts on that part of professionals who enable teacher training (Symeonidou 2017).

The indications that a shift has occurred in Turkey in relation to increased knowledge and training on inclusion resulting from initial 'training and development' is hopeful. However, our study's finding that a significant minority of teachers still resist inclusion also 
suggests that new ideas in training and professional development have not reached all professionals in schools. Connecting our findings to the argument that teacher educators do not generally research and analyse their own courses, and some can be reticent to attend continuous professional development training on inclusion (Symeonidou 2017), it is possible to conclude that our findings need to be unpacked with further qualitative research to examine teachers' perspectives on the processes and mechanisms through which specific training impacts on change.

Research into inclusive education argued for professional reflexivity to examine why teachers are personally, professionally, and politically resistant to change (Davis 2011; Davis and Watson 2001). This approach requires teachers to evaluate how their personal concepts impact on their practice, question why their attempts at inclusion fail (e.g. because they are unable to give up power), and to think about how they can use ideas of collaborative working and participation to foster joint problem-solving and co-operative service evaluation (Lawson and Sailor 2017).

Much of the 'special education' research on teacher education simplistically focusses on arguments about the structure and form of professional courses (e.g. Rouse and Florian 2012) rather than the need for the involvement of disabled children. This type of research wastes important time on irrelevant arguments, rather than actively encouraging teachers to question the nature, necessity, and utility of the existing power dynamic with an aim to relinquish power and find ways to foster change in partnership with disabled children. It wastes time and critical resources as other studies, such as those carried out in Australia, Canada, Hong Kong, and Singapore, have already demonstrated that the attitudes of student teachers improve regardless of the course structure (e.g. content infused or single unit) when they are exposed to well-designed training (Sharma, Forlin, and Loreman 2008). 
Many of the arguments regarding the structure of 'embedded' teacher training are based on one project in Aberdeen, Scotland (Symeonidou, 2017). Allan (2010) argues that one-off project approaches to inclusion in countries such as Germany, Austria, and the Netherlands were unsuccessful in the face of European Union's 'machine' approaches to education and did little to address teachers' uncertainty about inclusion. This study has demonstrated a need for much more complex and considered approaches to teacher training that enables teachers to understand suitable methods to remove disabling barriers to learning, ways to make reasonable adjustments that recognise the positive nature of impairment, and foster adaptable, flexible, child-led, and participatory approaches to inclusion.

It may also be the case that a tension exists in Turkey between 'inclusionists' (who seek to practice what they preach) and 'special educationists' who have been accused of adopting the discourse but not the practices of inclusion and re-defining the term 'inclusion' to justify practices that exclude disabled children (Symeonidou 2017; Allan 2014; Slee 2011; Florian 2007). Indeed, the affirmative model of disability may have meaning here. The inability of some professionals to engage with visually impaired children may relate to affirmative model ideas concerning stereotypes about specific impairments.

Teacher education occurs in contexts which are ideologically divided (between different teacher educators, researchers, policy-makers, parents, teachers, and children); the inability of inclusive approaches to overcome the legacy of 'special education' is one of the major challenges of teacher education for inclusion (Allan 2014; Symeonidou 2017). Many teachers who wish to be inclusive do not feel they have specific enough 'training' on visual impairment. When considered in terms of the affirmative model of disability, we came to the conclusion that these teachers will need to engage with practical examples of the positive aspects of visual impairment if their views are to change. 
In Turkey, we found a significant group of teachers who lacked knowledge of visual impairment were against inclusion. Research has connected the dated views of some professionals to practices that downplay and ignore children's abilities, views, feelings, rights, creativity, and diversity (Burman 1996, 2008; Woodhead and Faulkner 2000). This research has argued that a combination of structural (professional hierarchy) and attitudinal issues (e.g. dated and disablist child development ideas) lead some professionals to have low expectations concerning disabled pupils' abilities and to create their own barriers to inclusion (Alderson, 2000; Davis and Watson, 2001).

In our study, over 57.8 percent of teachers did not feel well prepared to teach visually impaired children and the majority appeared to be generally ambivalent about including visually impaired children in their classroom (in keeping with Kesiktaş and Akçamete 2011). In Scotland, schools are moving to a position where the mainstream classroom teacher or early years practitioner facilitate most solutions to learning barriers in participatory collaboration with parents and children and, where necessary, a range of other professionals provide support (e.g. family support professionals, therapists and support assistants). Davis and Deponio have argued that mainstream teachers must have both specialist knowledge of how to enable reasonable adjustments for children with specific impairments, as well as knowledge on inclusion (e.g. in relation to facilitating access to the social aspects of schooling) (Davis and Deponio 2014). The need for generic and specialist knowledge is supported by research into visual impairment and inclusion in the Republic of Ireland, where McCarthy and Shevlin argue for adaptable, flexible, and supportable teaching and learning methods to support inclusion of visually impaired children (McCarthy and Shevlin 2017). Through the findings of this study, we have raised questions regarding balancing traditional 'materialist' notions of the social model, which emphasises structural barriers to inclusion (e.g. inaccessible settings, lack of inclusive design, and prevalence of disablist attitudes), 
against later social models, which emphasise complex approaches to the notion of impairment effects. We believe our data reinforce the perspective that when promoting sociocultural approaches to inclusion we must not completely ignore childhood bodies (Corker and Shakespeare 2002; Davis and Watson 2001); we need to understand the interconnectedness of 'the body' to social processes, and consider the relationship between biological, cultural, individual, and social issues in children's lives, and we should examine the fluid relationship between biology, social contexts, and processes of change (Davis 2007; Prout 2005). Indeed, there is a need to connect teacher training on the everyday politics of notions of normality and bodily differences in schools with writing in disability studies that argues we should not conflate notions of disability with concepts of impairment. We should investigate the relationship between impairment, disability, the body, and society (e.g. Corker and Davis 2000; Paterson and Hughes 1999) in greater depth. Our findings complement the work of other studies which suggest teacher training should enable professionals to compare how different ideas to inclusion work in practice and gain an understanding of the complex nature of inclusion by analysing specific case-study examples (Allan 2014; Davis and Deponio 2014; Ravenscroft, Wazny, and Davis 2017).

Our positive findings concerning teachers, inclusion, and visual impairment hint at a more community-based and inter-relational basis for inclusion. For example, there is a sense of togetherness indicated by our findings in that the general education elementary teachers who felt prepared to include visually impaired children in their classrooms had knowledge of general inclusion, knowledge of inclusion for visual impairment, and felt their co-workers also had this knowledge. Indeed, other studies have also found that teachers who are supportive of inclusion identify the support of colleagues' as an imperative aspect of inclusive education (Boyle 2009; Boyle, Topping, and Jindal-Snape 2013). 
Our findings concerning the increased positivity of teachers in rural schools towards inclusion hinted at the possibility that in smaller, closer communities, teachers may have a greater positivity towards inclusion resulting from their community-based relationships. Research in Ireland, Catalonia, and Romania have associated transition and inclusion with complex "communities," where everyone is included whatever their various identities (Meegan and MacPhail 2006; Vrasmas and Vrasmas 2007; Puigdellívol et al 2017). In Ireland and the United Kingdom in particular, research has suggested that educational settings should become community-learning networks where participants recognise the strengths, assets, and capabilities of pupils, parents, and professionals (Puigdellívol 2017; Davis 2011; Dolan 2008; Kinsella and Senior 2008). Swain and French (2000) connect inclusion to communities that have an affirmative model of inclusion which does not seek to change disabled people but collectively recognises the value and validity of impairment and their strengths, abilities, diverse experiences, and positive identities. Our Turkish rural data raises questions as to why urban settings have less sense of community and inclusion. Some writers suggest that economic factors have impacted on the community participation of disabled youth and that disabled young people who live in socioeconomically disadvantaged households experience more issues with inclusion, experience greater exclusion, and are subjected to limited participation in mainstream education (Higashida 2017).

Other research has linked inclusive attitudes to a hierarchy of impairment and the intersections of class, gender, and ethnicity (Davis and Watson 2001, 2002). Some writers claim that teachers differentiate by impairment (e.g. they perceive students with a learning disability or behavioural problems to be more challenging than those with physical impairments) (Pearson, Chui, and Wong 2003). However, our findings suggest that, rather than actual childhood bodily differences, it is ignorance of the positives of impairment, a lack of knowledge of how to make reasonable adjustments relating to specific impairments, and a 
dearth of experience of inclusive practice that creates hierarchies of impairment. Our findings support the suggestion that teachers' beliefs about the education of students with disabilities are embedded in dominant educational discourses that centre on the otherness of some students, an unquestioned acceptance of the implicit assumptions, and deficit model perspectives of 'special education' create barriers to inclusion (Lalvani 2013). Our findings support the idea that student-teachers' attitudes change after they attend inclusive training events that involve disability equality training and interaction with disabled children and adults (Symeonidou, 2017; Carroll, Petroff, and Blumberg 2009; Carroll, Forlin, and Jobling, 2003). These studies connect a change in student teachers perceptions to disabled people's ability to help, in an affirmative model sense, the student teachers to overcome feelings of fear, discomfort, ignorance, and focus, in a social model sense, on how to remove barriers to learning.

Further research is required in Turkey to understand the complex interplay of issues, including teacher fears, that lead rural settings to be more positive about inclusion and to examine why teachers in urban settings are reticent towards inclusion. A key factor of positivity towards inclusion was found in the participants' responses to continuous professional development $(\mathrm{p}=0.001)$ (Tables 3 and 4$)$. This suggests that continuous professional development programs for teachers that include contact and engagement with disabled children and adults are worth investing in - whatever the age and experience of the teacher.

\section{Conclusion}

Overall, the results of our study in Turkey are broadly positive; most teachers support inclusion and see its direct benefits for children with visual impairment. The results support 
previous work that shows that knowledge and experience of fellow workers (Mulholland and O'Connor, 2016) play an important role in driving the positive attitudes of inclusion for the mainstream elementary school teachers. This, as well as the importance of continuous professional development (Ravenscroft, Wazny, and Davis, 2017), and the teacher's selfassessment of his or her openness to change are all factors that have significantly influence teachers' perspectives and their ability to foster the inclusion of visually impaired children within mainstream schools. The analysis suggests that rural teachers are more positive towards inclusion. In addition, increased training (both initial, and continuous professional development), and peer support practices support inclusion within Turkish elementary schools. This research is innovative and has revealed a shift in perspectives in Turkey; the majority of elementary school teachers (60 percent) commonly held positive attitudes towards inclusion, whereas previous research had shown that Turkish teachers did not hold inclusive beliefs. There is a need to balance positive notions of impairment and reasonable adjustment with generic notions of inclusion. Specifically, targeted training involving disabled children and adults could provide solutions to the lack of positivity in urban settings, but also greater research is required to understand the wider social issues that may impact teachers' attitudes in urban settings, such as the intersection of economic deprivation, issues of ethnicity, and disablist attitudes. To some extent, teachers' negativity is related to their lack of confidence in their own competency to provide adequately for the inclusion of children with visual impairment. However, it is important to note that this study focused on factors that influenced teacher attitudes towards inclusion in Turkey and thus has only addressed a small portion of what is required to provide quality education for visually impaired children. Additional research is needed on the content of initial teacher training, the number and profile of qualifications, as well as knowledge and skills of teachers working 
with visually impaired children to ensure that, as a country, Turkey can provide visually impaired children with the skills needed to succeed academically and in their own lives.

\section{Disclosure statement}

No potential conflict of interest was reported by the authors. 


\section{References}

Ahmmed, M., U. Sharma., and J. Deppeler. 2014. "Variables affecting teachers' intentions to include students with disabilities in regular primary schools in Bangladesh." Disability \& Society 29, (2): 317-331. doi:10.1080/09687599.2013.796878

Ainscow, M. 2000. "The next step for special education: Supporting the development of inclusive practices.” British Journal of Special Education, 272: 76-80.

Ainscow, M., P. Farrell and D. Tweddle. 2000. "Developing policies for inclusive education: a study of the role of local education authorities". International journal of inclusive education, 43: 211-229.

Akalın, S., S. Demir, B. Sucuoğlu, H. Bakkaloğlu, and F. İşcen. 2014. “The needs of inclusive preschool teachers about inclusive practices.” Eurasian Journal of Educational Research, 54: 39-60.

Alderson P. 2000. Young Children's Rights: Exploring Beliefs, Principles and Practice. London: Jessica Kingsley.

Allan, J. 2014. "Inclusive education and the arts". Cambridge Journal of Education, 44 (4): 511 523.

Allan, J. 2010. "The sociology of disability and the struggle for inclusive education." British Journal of Sociology of Education 31, (5): 603-619.

American Foundation for the Blind. 2011. "Educating students with visual impairments for inclusion society". American Foundation of the Blind. Accessed $5^{\text {th }}$ January 2018 http://www.afb.org/info/teachers/inclusive-education/35

Armstrong, D., and D. Galloway. 1994. "Special educational needs and problem behaviour: making policy in the classroom." Special Educational Needs Policy in the 90s, London, Routledge. 
Arslantekin, B. A. 2015. “The evaluation of visually impaired students' mobility skills." Education and Science, 401 (80): 37-49.

Avramidis, E., P. Bayliss, and R. Burden. 2000. "A survey into mainstream teachers' attitudes towards the inclusion of children with special educational needs in the ordinary school in one local education authority." Educational Psychology, 202: 191-211.

Barton, L, and F. Armstrong, eds. 2007. "Policy, experience and change: cross-cultural reflections on inclusive education”. Vol. 4. Dordrecht: Springer.

Batu, S., G. Kircaali-Iftar and Y. Uzuner. 2004. “Özel gereksinimli öğrencilerin kaynaştırıldı̆̆ bir kız meslek lisesindeki öğretmenlerin kaynaştırmaya ilişkin görüş ve önerileri [The opinions and suggestions of teachers who have integrated exceptional students in their classes in a secondary vocational school]". Ankara University Faculty of Educational Sciences Journal of Special Education, 5 (2): 33-50.

Borket, M., and C. De Tona. 2006. "Stories of HERMES: An analysis of the issues faced by young European researchers in migration and ethnic studies". Forum: Qualitative Social Research, 7, 3. Accessed January 15, 2017, from http://www.qualitativeresearch.net/index.php/fqs/article/view/133/287

Boyle, C. 2009. "The positive aspects of inclusion in secondary schools from the perspective of secondary school teachers". Unpublished doctoral dissertation. University of Dundee, UK.

Boyle, C., K, Topping, and D. Jindal-Snape. 2013. “Teachers' attitudes towards inclusion in high schools." Teachers and Teaching, 19 (5): 527-542.

Burch, L. F. 2018 "Governmentality of adulthood: a critical discourse analysis of the 2014 Special Educational Needs and Disability Code of Practice." Disability \& Society 33, (1): 94-114. doi: 10.1080/09687599.2017.1383231 
Burman, E. 1996. “Local, global or globalized? Child Development and international children's rights legislation.” Childhood, 3(1): 45-66. doi 10.1177/0907568296003001004.

Burman, E. 2008. Deconstructing developmental psychology (2nd ed.). London: Routledge

Çakıroğlu, E., and C. J. Çakıroğlu. 2003. "Reflections on teacher education in Turkey.” European Journal of Teacher Education, 26 (2): 253-264.

Cameron, C. 2008. Further towards an Affirmative Model, in Campbell, T et al (Eds) Disability Studies. Emerging insights and perspectives. The Disability press. Leeds.

Cameron, C. 2011 'Not Our Problem: Impairment as Difference, Disability as Role'. Journal of Inclusive Practice in Further and Higher Education, (3):2: 10-25

Carroll, A., C. Forlin, and A. Jobling. 2003. "The impact of teacher training in special education on the attitudes of Australian preservice general educators towards people with disabilities." Teacher Education Quarterly 30 (3): 65-79. doi:

$10.1080 / 09687590802469271$

Carroll, S. Z., J. G. Petroff, and R. Blumberg. 2009. "The impact of a college course where preservice teachers and peers with intellectual disabilities study together." Teacher Education and Special Education 32 (4): 351-364. doi:10.1177/0888406409346145.

Ciyer, A. 2010. Developing inclusive education policies and practices in Turkey: A study of the roles of UNESCO and local educator. Doctoral dissertation. Arizona State University. Accessed $5^{\text {th }}$ January 2018 from https://repository.asu.edu/items/8808.

Connors, C., and K. Stalker. 2006. “Children's experiences of disability: pointers to a social model of childhood disability”. Disability \& Society, 22 (1): 19-33, DOI: $10.1080 / 09687590601056162$.

Cook, T., J. Swain., S. French. 2010. "Voices from Segregated Schooling: Towards an inclusive education system.” Disability \& Society, 16 (2): 293-310, DOI: 10.1080/09687590120035852. 
Corker, M., J. M. Davis. 2000. "Disabled children-(Still) invisible under the law." Law, Rights and Disability: 217-238.

Corker, M. and T. Shakespeare. eds. 2002. Disability/postmodernity: Embodying disability theory. Bloomsbury Publishing.

Davis, J. M. 2007. "Analysing participation and social exclusion with children and young people. Lessons from practice." The International Journal of Children's Rights 15 (1): 121-146

Davis, J. M. 2011. Integrated Children's Services. SAGE.

Davis, J. M. and P. Deponio. 2014. "Analysing conflicting approaches to dyslexia on a European project: moving to a more strategic, participatory, strength-based and integrated approach." International Journal of Inclusive Education 18 (5): 515-534.

Davis, J.M., J. Ravenscroft, and N. Bizas, 2014. "Transition, inclusion and partnership: child, parent- and professional-led approaches in a European research project." Child Care in Practice, 21 (1): 33-49.

Davis, J. M. and N. Watson. 2001. "Where are the children's experiences? Analysing social and cultural exclusion in "special" and "mainstream" schools." Disability and Society, 16 (5): 671-687. doi: 10.1080/09687590120070060.

Davis, J.M. and N. Watson. 2002. “Countering stereotypes of disability: Disabled children and resistance." Disability/postmodernity: Embodying disability theory. 159-74.

Diken, H. İ., and B. Sucuoğlu. 1999. "Sınıfında zihin özel gereksinimli çocuk bulunan ve bulunmayan sınıf öğretmenlerinin zihin özel gereksinimli çocukların kaynaştırılmasına yönelik tutumların karşılaştırılması. [Comparison between experienced and inexperienced teachers' views toward inclusion of students with intellectual difficulties]." Ankara Üniversitesi Ĕ̈itim Bilimleri Fakültesi Özel Eğitim Dergisi, 23: 25-39.

Dolan, P. 2008. "Social support, social justice, and social capital: a tentative theoretical triad for community development." Community Development 39 (1): 112-119. 
Durak, S., and M. Erkilic. 2012. "Inclusive education environments from the teachers' perspective: an inquiry in a Turkish primary school." Children Youth and Environments, 221: 304-313.

Education Reform Initiative 2011. Türkiye'de kaynaştırma/bütünleştirme yoluyla eğitimin durumu [Mainstreaming/Inclusive Education in Turkey]. İstanbul: Mega Basim.

Erkilic, M. and S. Durak. 2013. "Tolerable and inclusive learning spaces: an evaluation of policies and specifications for physical environments that promote inclusion in Turkish primary schools." International Journal of Inclusive Education, 17 (5): 462-479. doi $10.1080 / 13603116.2012 .685333$

Florian, L. 2008. "Inclusion: special or inclusive education: future trends." British Journal of Special Education, 35 (4): 202-208.

Florian, L. 2007. "Reimaging Special Education.” In The SAGE Handbook of Special Education, edited by L. Florian, 7-20. Los Angeles, CA: Sage Publications.

Forlin, C., T. Loreman, U, Sharma, and C. Earle. 2009. "Demographic differences in changing preservice teachers' attitudes, sentiments and concerns about inclusive education." International Journal of Inclusive Education, 13 (2): 195-209.

Garth, B., and R, Aroni. 2003. “'I Value What You have to Say'. Seeking the Perspective of Children with a Disability, Not Just their Parents." Disability \& Society 18 (5): 561-576. doi 10.1080/0968759032000097825.

Hastings, R. P., and S Graham. 1995. “Adolescents' perceptions of young people with severe learning difficulties: The effects of integration schemes and frequency of contact." Educational Psychology 15 (2): 149-159.

Higashida, M. 2017. "The relationship between the community participation of disabled youth and socioeconomic factors: mixed-methods approach in rural Sri Lanka." Disability \& Society 32, (8): 1239-1262. doi 10.1080/09687599.2017.1351921. 
Higgins, N., J. MacArthur, and C. M. Rietveld. 2006. "Higgledy-piggledy policy: Confusion about inclusion." Accessed January $6^{\text {th }} 2018$. https://ir.canterbury.ac.nz/handle/10092/5217

Joy, R., and E. Murphy. 2012. "The inclusion of children with special educational needs in an intensive French as a second-language program: From theory to practice.” Canadian Journal of Education, 35 (1): 102-119.

Kesiktaş, A. D., and A. G. Akçamete. 2011. "The relationship of personnel preparation to the competence of teachers of students with visual impairments in Turkey". Journal of Visual Impairment \& Blindness 105 (2): 108.

Kinsella, W., J. Senior. 2008. "Developing inclusive schools: a systemic approach." International Journal of Inclusive Education 12 (5-6): 651-665. DOI: 10.1080/13603110802377698

Kunc, N. 1992. The need to belong: Rediscovering Maslow's hierarchy of needs. In R. Villa, J. Thousand, W. Stainback, and S. Stainback Eds., Restructuring for caring and effective education: An administrative guide to creating heterogeneous schools pp. 72-86. Baltimore: Brookes.

Lalvani, P. 2013. Privilege, compromise, or social justice: Teachers' conceptualizations of inclusive education. Disability \& Society 28 (1): 14-27. doi: $10.1080 / 09687599.2012 .692028$.

Lane, C. M. 2008. Predictors of successful inclusion for children with vision impairment in early education Unpublished doctoral thesis. Curtin University of Technology, Perth, Australia. Accessed January $20^{\text {th }} 2018$ https://espace.curtin.edu.au/handle/20.500.11937/1610

Lawson, H.A., and W. Sailor. 2017. "Integrating Services, Callaborating, and Developing Connections with Schools." Focus on Exceptional Children 33 (2): 1-21.

Lewis, S., M.E. Savaiano, K. Blankenship, and K. Greeley-Bennett. 2014. "Three areas of the expanded core curriculum for students with visual impairment: Research priorities for 
independent living skills, self-determination, and social interaction skills”. In D. Hatton Ed., Current issues in the education of students with visual impairments, International Review of Research in Developmental Disabilities Vol. 46: 207-252 Burlington, VT: Academic Press.

Lohmeier, K., K. Blankenship, and P Hatlen. 2009. "Expanded core curriculum: 12 years later." Journal of Visual Impairment \& Blindness. 103 (2): 103.

McCarthy, P., M. Shevlin. 2017. "Opportunities and challenges in secondary education for blind/vision-impaired people in the Republic of Ireland." Disability \& Society 32 (7): 1007-1026. doi: 10.1080/09687599.2017.1337564.

McGrath, C., Rudman, D.L., Trentham, B., Polgar, J. and Spafford, M.M., 2017. Reshaping understandings of disability associated with age-related vision loss (ARVL): incorporating critical disability perspectives into research and practice. Disability and rehabilitation, 39(19), pp.1990-1998.

Meegan, S., and A. MacPhail. 2006. "Irish physical educators' attitude toward teaching students with special educational needs." European Physical Education Review, 12. (1): 75-97.

Meekosha, H. and Shuttleworth, R., 2009. What's so 'critical'about critical disability studies? Australian Journal of Human Rights, 15(1): 47-75.

Melekoglu, M. A. 2014. "Characteristics of inclusive classrooms in Turkey.” Journal of The International Association of Special Education, 152: 24-30.

Melekoglu, M. A., O. Cakiroglu, and K. W. Malmgren. 2009. "Special education in Turkey." International Journal of Inclusive Education 13 (3): 287-298.

Metin, N., H. Çakmak. 1998. “İlköğretim okullarındaki ĕgitimcilerin özürlü çocuklarla normal çocukların kaynaştırıldı̆̆ı programlar hakkındaki düşüncelerinin incelenmesi. [The examination of primary school teachers' views about inclusive programs].” Paper 
presented at 8th National Special Education Conference Proceedings, Trakya University, Edirne pp. 128-139. Edirne: n.p..

Ministry of National Education, National Education Statistics, 2017. "Table 1.15: Number of schools, students, teachers and classrooms in special education institutions." Accessed $5^{\text {th }}$ January 2018. http://sgb.meb.gov.tr/www/icerik_goruntule.php?KNO=270.

MoNE Ministry of National Education 1990. Körler ilkokulu ögretim programı [The Curriculum for the Blind]. Turkey, Ankara: Milli Eğitim Basımevi.

MoNE Ministry of National Education. 2008. Kaynaştırma yoluyla eğitim uygulamaları genelgesi [Circular for educational practices via inclusion]. Accessed $5^{\text {th }}$ January 2018 https://orgm.meb.gov.tr/meb_iys_dosyalar/2015_10/08101631_kaynatrmayoluylaeitimuy gulamasgenelgesi.pdf

MoNE Ministry of National Education. 2010. Okullarımızda neden niçin nasıl kaynaştırma: yönetici oğretmen ve aile kllavuzu [The why and how of inclusion in our schools: A guide for administrators, teachers and families]. Accessed $7^{\text {th }}$ January 2018 http://orgm.meb.gov.tr/alt_sayfalar/yayimlar/kaynastirma/kaynastirma.pdf

Mulholland, M., and U. O'Connor. 2016. "Collaborative classroom practice for inclusion: perspectives of classroom teachers and learning support/resource teachers." International Journal of Inclusive Education 20 (10): 1070-1083.

Mushoriwa, T. 2001. "A study of the attitudes of primary school teachers in Harare towards the inclusion of blind children in regular classes.” British Journal of Special Education 28 (3): 142-147.

Özaydın, L. and A. Çolak. 2011. “Okul öncesi öğretmenlerinin kaynaştırma eğitimine ve okul öncesi eğitimde kaynaştırma eğitimi hizmet içi eğitim programına ilişkin görüşleri [The views of preschool education teachers over mainstreaming education and over in-service 
education program of mainstreaming education at preschool education]." Kalem Egitim ve Insan Bilimleri Dergisi, 1 (1): 189-226.

Panayotova, K. 2009. "Report on the Employment of Disabled People in European Countries". Bulgaria, Utrecht, (ANED).

Paterson, K. and B. Hughes.1999. Disability studies and phenomenology: The carnal politics of everyday life. Disability \& Society 14 (5): 597-610. doi: 10.1080/09687599925966.

Pearson, V., E, Lo, E. Chui, and D. Wong. 2003. “A heart to learn and care? Teachers' responses toward special needs children in mainstream schools in Hong Kong." Disability and Society, 18 (4) 89-508. doi: 10.1080/0968759032000081020.

Pogrund, R. L., and K. A. Wibbenmeyer. 2008. "Interpreting the meaning of the terms certified and highly qualified for teachers of students with visual impairments." Journal of Visual Impairment \& Blindness 102 (1): 5-15.

Polat, F. 2011. “Inclusion in education: A step towards social justice.” International Journal of Educational Development 31 (1): 50-58.

Prout A. 2005. The Future of Childhood. London: Routledge.

Puigdellívol, I., S. Molina, D. Sabando, G. Gómez and C. Petreñas. 2017. "When community becomes an agent of educational support: communicative research on Learning Communities in Catalonia.” Disability \& Society 32 (7): 1065-1084, DOI: 10.1080/09687599.2017.1331835.

Rakap, S. and L. Kaczmarek. 2010. "Teachers' attitudes towards inclusion in Turkey”. European Journal of Special Needs Education 25 (1): 59-75.

Ratcliffe, M., C. Burd, K. Holder, and A. Fields. 2016. "Defining rural at the US Census Bureau: American community survey and geography brief.” ACSGEO-1. Washington, DC. Accessed 20 January 2018 https://www.census.gov/content/dam/Census/library/publications/2016/acs/acsgeo-1.pdf 
Ravenscroft, J., K. Wazny, J.M. Davis. 2017. "Factors associated with successful transition among children with disabilities in eight European countries." PloS one 12 (6): e0179904.

Rouse, M., and L. Florian. 2012. "Inclusive Practice Project: Final Report.” Accessed January 22, 2018. http://www.efds.co.uk/assets/0000/6672/OO195.pdf

Ryan, T. G. 2009. "Inclusive attitudes: a pre-service analysis.” Journal of Research in Special Educational Needs 93: 180-187.

Sak1z, H., and C. Woods. 2015. "Achieving inclusion of students with disabilities in Turkey: Current challenges and future prospects. " International Journal of Inclusive Education 19 (1): 21-35.

Saunders, A. L. 2012. Inclusion of middle school students with visual impairments in the general education classroom Doctoral dissertation. California Lutheran University. Accessed January $25^{\text {th }} 2018$ https://search.proquest.com/openview/cdb3d78aaba75de96b5548923cf82f1e/1?pq$\underline{\text { origsite }}=$ gscholar $\& \mathrm{cbl}=18750 \& \operatorname{diss}=\mathrm{y}$

Sharma, U., C. Forlin, and T. Loreman. 2008. 'Impact of Training on Pre-Service Teachers' Attitudes and Concerns about Inclusive Education and Sentiments about Persons with Disabilities.” Disability and Society 23 (7): 773-785. DOI 10.1080/09687590802469271

Slee, R. 2011. The Irregular School. New York: Routledge

Special Education Services Bylaws, Official Gazette, 07.21.2012 No. 28360. Accessed January $28^{\text {th }} 2018$ https://orgm.meb.gov.tr/meb_iys_dosyalar/2012_10/10111226_ozel_egitim_hizmetleri_y onetmeligi_son.pdf

Special Education Statutory Decree, Law No.: 573, Official Gazette, 06.06.1997, No. 2301, enacted: 05.30.1997. Accessed January 28th 2018. 
https://orgm.meb.gov.tr/meb iys_dosyalar/2012_10/10111011_ozel_egitim kanun hukm unda_kararname.pdf

Symeonidou, S. 2017. "Initial teacher education for inclusion: a review of the literature." Disability \& Society 32 (3): 401-422. doi: 10.1080/09687599.2017.1298992.

Swain, J. and French, S. (2000) Towards an Affirmation Model of Disability. Disability \& Society, 15 (4). pp. 569-582.

Uysal, A. 2004. “Kaynaştırma uygulaması yapan öğretmenlerin kaynaştırmaya ilişkin görüşleri [The views of experienced teachers towards inclusive education].” Paper presented at 13th National Special Education Congress: 121-135. Ankara: Kök Yayıncılık.

Vrasmas, T., and A. Vrasmas. 2007. "Inclusive education in Romania." In Regional Preparatory Workshop on Inclusive Education Eastern and South-Eastern Europe. 2007.

Wall, R. 2002. "Teachers' exposure to people with visual impairments and the effect on attitudes toward inclusion." RE: view 34 (3): 111-119.

Woodhead, M., and D. Faulkner. 2000. "Subjects, objects or participants? Dilemmas of psychological research with children”. Research with children: Perspectives and practices: 9-35. 
